Richard Goodwin: A Short Appreciation Author(s): Meghnad Desai and Paul Ormerod

Source: The Economic Journal, Vol. 108, No. 450 (Sep., 1998), pp. 1431-1435

Published by: Blackwell Publishing for the Royal Economic Society

Stable URL: http://www.jstor.org/stable/2566188

Accessed: 09/09/2008 05:42

Your use of the JSTOR archive indicates your acceptance of JSTOR's Terms and Conditions of Use, available at http://www.jstor.org/page/info/about/policies/terms.jsp. JSTOR's Terms and Conditions of Use provides, in part, that unless you have obtained prior permission, you may not download an entire issue of a journal or multiple copies of articles, and you may use content in the JSTOR archive only for your personal, non-commercial use.

Please contact the publisher regarding any further use of this work. Publisher contact information may be obtained at http://www.jstor.org/action/showPublisher?publisherCode=black.

Each copy of any part of a JSTOR transmission must contain the same copyright notice that appears on the screen or printed page of such transmission.

JSTOR is a not-for-profit organization founded in 1995 to build trusted digital archives for scholarship. We work with the scholarly community to preserve their work and the materials they rely upon, and to build a common research platform that promotes the discovery and use of these resources. For more information about JSTOR, please contact support@jstor.org. 
The Economic Journal, 108 (September), 1431-1435. (C) Royal Economic Society 1998. Published by Blackwell Publishers, 108 Cowley Road, Oxford OX4 1JF, UK and 350 Main Street, Malden, MA 02148, USA.

\title{
RICHARD GOODWIN: A SHORT APPRECIATION
}

\author{
Meghnad Desai and Paul Ormerod
}

Richard Goodwin, a self-confessed 'lifelong though wayward Marxist' (1983), was interested throughout his active academic career, spanning some fifty years, in the problem of the dynamics of a capitalist economy. Though he had no formal training as a mathematician, he was acknowledged by Le Corbellier to have contributed to the theory of oscillations, and was thus well equipped to model such dynamics.

His work was based upon the premise that capitalism can only be properly understood as a non-linear system, and its overall theme is perhaps best summarised by a remark in one of his latest papers: 'Capitalism is almost always to be found in non-steady state, the explanation being that it is a game played simultaneously by millions of players who cannot possibly have the information necessary to play it well, let alone optimally. The result is a system that bifurcates back and forth between a stable and an unstable state: a growth equilibrium state that is unstable is of purely theoretical interest, since it is the one place the system will never remain'. (Goodwin (1987) p. 158).

Such a view accords closely with that expressed by Hayek, who wrote in his famous article on the trade cycle (1935) that it is ...[not] clear that we can apply the [economic] concept of equilibrium to the actions of a great number of persons, whose successive responses to the actions of their fellow-beings necessarily takes place in time, and which can be represented as a timeless equilibrium relationship only by means of unrealistic special assumptions'. Hayek, of course, lacked the mathematical ability of Goodwin to attempt to translate his insights into a formal model.

But the insight of both Goodwin and Hayek, namely that the analysis of the macro-dynamics of capitalism required an approach which was fundamentally different to that of convention, set them apart from the economic mainstream. In esssence, both men saw capitalism as what we now call, following the nonlinear scientific revolution of the closing decades of this century, a selforganising system. The complex interaction of individual agents implies, for example, that government intervention is not needed to revive the economy in a depression. The natural rhythms of the system itself ensure that a recovery takes place. But in stark contrast to the model of orthodox economics, there is no guarantee that markets clear in this model, and the average rate of unemployment, for example, during the course of the economic cycle could be either high or low.

Goodwin's views set him somewhat apart from Keynes's immediate disciples, with whom one might have imagined would have existed more common cause, though he personally admired his Cambridge colleagues, especially Joan Robinson and Richard Kahn. But, in a number of ways, Goodwin's work was 
more general than that of Keynes. Keynes wrote his magnum opus in the 1930s against the background of what was by far the most serious recession ever to have hit the Western economies. In Western Europe, the average fall in output from its peak to the trough of the recession was $10 \%$, and almost $30 \%$ in Canada and the United States.

It seemed entirely possible that such deep recessions might be an integral feature of capitalism, and this idea dominated Keynes's work. But we now know, more than 60 years later, that the early 1930 s are a quite unique episode in the history of the developed world. The work of Maddison (1995), for example, shows that the early 1930s remains the only episode of a deep, general economic recession. Within individual countries in peace-time conditions, annual falls in output of more than 5 or $6 \%$ are unusual, and are typically followed by a rapid revival.

Most of Goodwin's work was carried out before the modern explosion of interest in non-linear systems, which makes his efforts to understand capitalism in a rigorous way from this perspective all the more remarkable. He had worked with Roy Harrod in the late 1930's when the General Theory was still fresh and revolutionary and helped in Harrod's attempts at formulating growth theory, a problem which Keynes himself never addressed. He did this by showing Harrod a review of Harrod's book on The Trade Cycle by Tinbergen in a German journal. Tinbergen had pointed out that Harrod's model of the cycle was mathematically inadequate since it only had a first order differential equation which was all right for growth but not for cycles. Harrod was apparently annoyed to be told this, but soon after that came out with his article in this JOURNAL on growth which had the first order equation (though for a slightly different account see Harcourt (1993) and Vellupillai (1990)).

Goodwin also knew that the Hansen-Samuelson model of the Multiplier Accelerator does not generate non damped cycles, a point which was later demonstrated to the profession by the simulation of the Klein-Goldberger Model (an enlarged version of the Multiplier Accelerator Model) by Frank and Irma Adelman (1959). Goodwin always focused on the theory of a flexible accelerator which would add the nonlinearity missing in the Hansen-Samuelson model.

Hicks, in his book on the Trade Cycle (1949), had generated a persistent cycle from a Multiplier Accelerator model but as Goodwin pointed out in his review article (1950) the nonlinearities Hicks had introduced were simply the ceiling - the full employment/full capacity barrier and the floor set by the fact that while net investment can be negative gross investment cannot be so.

Goodwin addresssed the non linearity problem by adapting a special case of the oscillator. When the actual capital stock was below desired capital stock investment took a certain constant value. As soon as the desired level was reached investment slowed down to zero and in the process made the actual capital stock go above the desired capital stock via the income effects of lower investment. In this phase Goodwin assumed that disinvestment would be another constant figure.

This simple scheme gives a totally endogenous limit cycle which is by 
definition self sustaining. This is the great contribution of his Econometrica 1951 article. Goodwin extends the limit cycle to add a growth trend due to technological progress as well as any other extensions. It is a wide ranging article. It was however not to prove a seminal one. Indeed, in the 1950's cycles went out of fashion; growth became the big topic. Goodwin at the same time left the United States because of McCarthyism. The two are not unconnected: cycles were thought to be an admission of weakness and growth the strength of capitalism. It was the time in the Cold War to accentuate the positive.

A parallel strand in Goodwin work was the micro structural modelling of the economy. In his Multiplier as a Matrix (1949) Goodwin shows that by tracing out the microeconomic impact of additional expenditure through the sectors ' $[\mathrm{T}]$ he dynamic matrix multiplier can be shown to have necessarily an oscillatory element in its behaviour'. Goodwin demonstrates this by showing that the pattern of expenditures over time will form an asymmetric square matrix A. The latent roots of the Multiplier as matrix are given by

$$
[\mathbf{I}-\lambda \mathbf{A}] \mathbf{y}(\mathbf{t})=\mathbf{0} \text {. }
$$

As Goodwin explained in a subsequent 1950 article in this JournAL, 'Because of the asymmetry of the matrix $\mathbf{A}$ and because of the zero along the principal diagonal, they [the roots] cannot be all real and positive. Therefore for arbitrary initial conditions, it is always possible to have oscillations'.

This was also the article which first cited the Froebenius Theorem, suggested to him, as Goodwin acknowledged, by a young student called Robert Solow. This discovery of the Froebenius result inspired further work by Goodwin of growth processes and the latent roots of the Input Output matrix of a growing economy. The climax of this was the article in the Polenske Skolka volume (1976) where Goodwin shows that in a Sraffa system there are not just one but multiple standard commodities each corresponding to a latent root.

But long before that article, Goodwin had made a decisive innovative break in analysing the dynamics of capitalism. This was his short article entitled 'A Growth Cycle' in the Festschrift for Maurice Dobb (1967). This is a two equation model, adapting the Lotka-Volterra system of differential equations which is used widely in predator-prey models in biology.

In this article, Goodwin ignores the Keynesian explanation of the cycle. There are no effective demand problems. All saving is carried out by capitalists and all is invested in a constant capital-output ratio technology. There is no money illusion in the wage bargain but there is a real wage Phillips Curve. By adding exogenously given constant rates of growth of population and labour productivity, Goodwin gets the result that the system will oscillate around the singular equilibrium point, whilst never approaching it even asymptotically. The amplitude of the cycle will be determined by the initial conditions and the length by the latent roots which are imaginary. In his later work Goodwin elaborated upon this model and explored different variations of the LotkaVolterra model (1987). The motto of this later work was the same as before 'Capitalism grows but never steadily'.

The 1967 paper was undoubtedly Goodwin's greatest work. It is a paper of (C) Royal Economic Society 1998 
extraordinary generality, which in a mere half-dozen pages covers the following themes:

(1) The two key factors which distinguish capitalism from all other economic systems are sustained growth in the long-term, and the existence of fluctuations around the trend rate of growth. Goodwin's paper gives an economic explanation of both these phenomenon.

(2) The paper focuses explicitly on the distribution of national income between profits and wages as the source of both long-term growth and the economic cycle. Goodwin's paper restores the importance of profits to the understanding of capitalism, a concept which was central to the work of Smith, Ricardo and Marx, but which subsequently practically disappeared in macroeconomics, except occasionally in examples such as the important empirical work at the NBER of Mitchell (1923), culminating in his notable volume with Burns (1946) and the theoretical work of Kalecki.

(3) The existence of a closed cycle with a centre at its singular point in the model offers a different concept of equilibrium to that of conventional economics. Instead of the idea of a unique equilibrium point, for example, the perspective of equilibrium which the paper gives is of a distribution of the amount of time which the system spends in various states.

(4) There is no guarantee in the model that the labour market will clear. In other words, no assumption is made that the average rate of unemployment over time will be low. The tendency for umemployment to persist at fairly high levels for long periods of time in capitalist economies has recently led Arrow to describe it as an 'empirical refutation' of general equilibrium theory (1994).

(5) The paper draws attention to the importance of initial conditions and hence, implicitly, to path-dependence and the role of economic history. The position of the closed cycle in profit/unemployment space is determined entirely by initial conditions, so that two economies whose average growth and unemployment rates were identical could nevertheless experience quite different histories in terms of cyclical fluctuations.

(6) Methodologically, the paper points the way to the use of dynamic systems techniques to the understanding of the dynamic process of capitalism. In this respect, the paper was years ahead of its time.

(7) Finally, the paper suggests a political theory to account for the successful absorption of the working class by capitalism. It is easy to forget in the mid1990 s that it was only relatively recently in historical terms - perhaps as late as the 1960 s in Europe - that the capitalist market economies showed that they offered a decisively superior form of economic organisation. Goodwin's paper gives an account of why, even in a system in which labour and capital were mutually antagonistic, the two could nevertheless remain locked together in a successful, symbiotic relationship.

Of course, the 'Growth Cycle' paper is far from perfect. For example, it lacks explicit micro-foundations. And the underlying degrees of regularity in LotkaVolterra systems, even when clothed with substantial dynamic noise, is much greater than is observed in actual business cycle data, a fact which Goodwin

(C) Royal Economic Society 1998 
intuitively recognised in his later work such as Chaotic Economic Dynamics (1990).

But regardless of any qualifications or criticisms which may be made of Goodwins's work, the overall impression which it leaves is that it stemmed from the strikingly original mind of a man who in many ways was years ahead of his time. The whole emphasis of his work was on the need to focus on a different idea of equilibrium from that normally used in economics, in which the system is constantly in change and the appropriate concept is the proportion of time which the system spends in various states of the world. This is the whole thrust of the non-linear scientific revolution, which will eventually embrace, kicking and screaming, the economics profession.

\section{London School of Economics}

Post-Orthodox Economics, London

\section{References}

Goodwin, R. M: (1983) Essays in Linear Economic Systems London: Macmillan.

Goodwin, R. M. (1987) Essays in Economic Dynamics London: Macmillan. (Most of Goodwin's papers between 1945 and 1983 are reprinted in these two volumes)

Goodwin, R. M. and Punzo, L. (1987) The Dynamics of a Capitalist Economy. Boulder Colorado: Westview Press.

Adelman, F. and Adelman, I. (1959) 'The dynamic properties of the Klein-Goldberger model econometrics.'

Arrow, K. (1994) 'Problems mount in application of free market theory', Guardian, London, 3 January.

Burns, A. F. and Mitchell, W. C. (1946) Measuring the Business Cycle, NBER.

Harcourt, G. (1993) Post-Keynesian Essays in Biography, London: Macmillan.

Hayek, F. (1935) 'Price expectations, monetary disturbances and malinvestments', English version of 1935 German paper in Profits, Interest and Investment, Routledge and Sons, 1939.

Hicks, J. R. (1949) A Contribution to the Theory of the Trade Cycle Oxford: Oxford University Press.

Maddison, A. (1995) Monitoring the World Economy 1820-1992, Paris: OECD.

Mitchell, W. C. (1923) Business Cycles and Unemployment, NBER.

Velupillai, R. (1990) Non-linear and Multisectoral Macrodynamics, London: Macmillan. 